\title{
Rhizosphere Management: A Novel Approach for Improving the Crop Productivity
}

\author{
Arvind Kumar*, V.P. Singh, D.S. Pandey and Rajeew Kumar \\ Department of Agronomy, G.B. Pant University of Agriculture and Technology, \\ Pantnagar, Udham Singh Nagar (UK) 263145, India \\ *Corresponding author
}

\section{A B S T R A C T}

\section{Keywords}

Rhizosphere management, Plant management, Soil management, Soil health, Plant productivity

Article Info

Accepted:

18 February 2019 Available Online: 10 March 2019
This paper can be focused on rhizosphere management to improve plant performance and soil health. The rhizosphere is the interacting soil zone between plant and soil biota. It could affect the plant nutrient availability through soil biological activity. It can be manipulated through plant management (selection of plant species, change in cropping pattern, intercropping etc.), soil management (addition of organic carbon or organic manure), microbial management (selection of biotic community), and system approach where plant, soil and microbial can be improved simultaneously. So, rhizospheric management can help us to improve soil health and plant productivity.

\section{Introduction}

The increasing inputs use, enhanced nutrient losses from soil, and increased stress (biotic and abiotic) on a plant that causes low NUE and plant performance (Bommerco et al., 2013). In India, It creates more focus on nutrient management, especially synthetic fertilizer to satisfy the crop demand as well as food demand. We haven't much concern toward soil rhizospheric properties and plant characters (plant sink capacity, root capacity, and root morphology), plant nutrient utilization to enhance crop productivity
(Neumann et al., 2009; Zhang, et al., 2010). Plants don't only use the soil as supporting material but plant releases some organic substances that influence the soil properties. This plant influenced soil volume can be known as rhizosphere (Dessaux et al., 2016). In the early 19 century, this biologically more active soil volume near root zone termed as "rhizosphere" (Hartmann, 2008). The rhizosphere is the root adjacent area which causes the favorable environment to the growth of plant through microbial activity (Rhizobium, Azotobacter, Mycorrhizae fungi and Cyanobacterium) that is prerequisite for 
improving NUE and efficient crop production (Haichar et al., 2012). The crop output can be enhanced through integrated management of synthetic fertilizers, crop growing practices, and soil-plant interactions without hampering on ecosystem process (Ryan et al., 2009).

Now a day's alteration required to address the rhizospheric issues i.e. detection, analysis of root system under field condition, study the root mediated physicochemical properties into rhizosphere for root activity evolutions, molecular and physiological characterization of rhizosphere related regulatory processes and rhizosphere manipulating strategies for improving crop productivity (Neumann et al., 2009). The physical, biological and chemical behavior is the output of many complexes, and interacting rhizospheric processes that affected by the plant mechanism, soil type, environmental factors and the microbial communities itself (Ryan et al., 2009). The healthy soil biology can be managed through technological interventions, improvement, and breeding of the soil biotic community for improving as plant growth, nutrient uptake, and root characteristics. Also, the plants could be selectively engineered for various novel and interested beneficial plant traits. Plants availability of nutrients can also be improved by the application of soil amendments (Ryan et al., 2009). Further, it can be enhanced by utilizing the plant root microbe communications into genetic engineering through several meditating chemical compounds. So, we require much attention toward study the rhizospheric environment and the root system of plants to improving the yield potentials of our crops to meet the food demand projected for next half century (Zhang, et al., 2010). This review is done with the aim of strengthening up the knowledge of rhizospheric physicochemical, biological process and their management through various plant, soil, microbial approaches, plant and microbiome engineering methods. Also to intensely the attention toward rhizosphere enrichment and feeding for improving plant use efficiency.

\section{Rhizosphere}

The word "rhizosphere" to refered by the Greek word "Rhiza" which means root (Hiltner, 1904; Hartmann et al., 2008). Basically, The rhizosphere is the part of soil which is most affected by the mutual relationship of plant and microbial communities and differentiated from bulk soil (Haichar et al., 2014). It helps to improve the plant nutrients availability and biological activity through plant driven carbon as Rhizodeposits (Larsen et al., 2015). This biological activity can be influenced by the various factors like a plant, soil, and climate that is known as "rhizospheric effect". It can be presented by $\mathrm{R} / \mathrm{E}$ ratio. The $R / E$ ratio can 2 to 20 showed normal range. (Whipps, 2001). The extent of rhizosphere in the soil can be depended upon the root system and microbial community because the vigorous root system and VAM can significantly increase the rhizospheric zone. The plant release compounds and microbial activity are a help to determine the spread of rhizospheric influence in the soil. According to this rhizosphere can be categories into different layers which spread from plant root to bulk soil (McNear Jr., 2013).

\section{Rhizospheric layers}

The rhizosphere can be influenced by the root development and root release compounds into the soil. So, on the basis of relative proximity, Rhizodeposits and microbial influences, the rhizosphere divided into 3 layers that spread from root out layer to adjacent soil (McNear Jr., 2013).

a. The endorhizosphere are the most intense rhizospheric activity zone at the outer layer of the plant root surface. 
b. The rhizoplane is the intermediate zone or actual root-soil interface zone which inner layer directly surrounded to the root including the root epidermis and mucilage and out layer to ectorhizosphere.

c. The ectorhizosphere which is outer most layer of rhizosphere up to bulk soil.

\section{The rhizosphere manipulations}

The plant and biotic communities are the crucial factors that influence the rhizosphere because both are the parts of rhizosphere and help to shape the rhizosphere. However, these basic factors some external factor also influence the rhizosphere development by influencing the activity and development of plant and microbial communities likewise temperature, moisture, aeration, organic matter etc.

\section{Role of plants in rhizosphere development}

Plant root plays most active role in designing the soil and rhizospheric environment (Costa et al., 2006; Haichar et al., 2012). The plant community assimilates the photosynthates and shifted them toward the root and various plant parts which can be further use for plant physiological and metabolic requirements (Larsen et al., 2015). The plant community help to design the rhizosphere by the plant root system and releasing various low and high molecular weight carbon compounds which are the source of food for microbial communities which influences the rhizosphere biology and signaling (Jones et al., 2009). The rhizospheric shape is the functions of microbial colonization within root and rhizosphere, properties and amount of root released compounds, plant and microbial interaction and signaling and plant resistance factors (Haichar et al., 2014). The sensing and signaling, diversifying exudation produced from plants and selective activity of microbes can be considered for the rhizospheric activity because plant influences the microbial activity significantly through releasing of the various carbon compounds (Lange et al., 2015). These carbon compounds are known as Rhizodeposits which having various forms of organic substances exudates from the plant root (Jones et al., 2009). Plant shoot and root litter deposition also add much amount of organic substances into the soil that can be used by microbial communities to drive the various soil processes viz., mineralization, immobilization, nitrification, denitrification, carbon cycling, and $\mathrm{P}$ solubilization etc. (Jones et al., 2009). The plant community influences the microbial population, their abundance, and activity with the root system (Philippot et al., 2009). The rhizospheric zone can accelerate the microbial activity in root zone with more exudation of organic compounds from plant communities with the response of various factors as plants, soil and climatic factors (Larsen et al., 2015). All the rhizospheric biota, their activity, and various rhizospheric processes are affected by the plant root system and their amount of carbon exudates. So, the plants play crucial role in the rhizosphere development and their community (Table 1).

\section{Role of microbes in rhizosphere development}

A plant interacts with their biotic environments through secretion of more variable compounds into the rhizosphere (van Dam and Bouwmeester, 2016) which made Soil more diverse in its biological habitat. The soil is consist of millions of bacteria, widespread fungal hyphae, number of nematodes, protozoans, earthworms and other arthropods (Bardgett and Van der Putten, 2014). All the rhizospheric community has oligotrophic in nature so it occurs near the root surface where carbon found in abundance 
(). It influences the plant nutrients dynamics through root and microbial activity (Philippot et al., 2013; Larsen et al., 2015). This biological activity can be managed by the plant through secretions and diffusion of various forms of low and high molecular weight carbonic substances (McNear et al., 2013).

The plant root released carbonic substances is popularly known as Rhizodeposits (Jones et al., 2009). However, microbes can also release some carbon compounds used by the plant as a nutrient source, biocontrol agent and signaling compounds for soil biotic community. The extent of release of these organic substances can determine the rhizospheric volume because more availability of exudates can create a more diverse and wide rhizospheric activity zone. However, this can be depended on decomposition rate and carbon storage into the soil system (Lange et al., 2015). The rhizospheric microbial community benefited the soil ecosystem by serving functions of decomposing of organic matter, nutrients availability through solubilization and mobilization, root pests control and rhizospheric signaling (Jones et al., 2009; Philippot et al., 2013). However, various pathogenic microbes, denitrifying bacteria, protozoan, and nematodes are deleterious to rhizospheric processes. This process can help to shape the rhizosphere because Rhizodeposits supported the biome activity in the soil system. The rhizospheric microbial community functions and structure have been influenced by soil types and host plant and soil environment conditions (Haichar et al., 2008). So, the soil biotic community which is under the influence of plants can also play an important role in designing the rhizosphere through various biological processes such as nutrient mobilization, signaling pathway, and biocontrol agents.

\section{Other factors}

Other factors such as soil structure, temperature, water movement, aeration, soil $\mathrm{pH}$ and heavy metals concentration into the soil cause severely adverse impacts on both plant and biotic community development which influence the rhizosphere designing. Soil erosion accelerated by unsustainable agricultural activities can break down the soil structure which that negatively coincided with rhizospheric development (Jiang et al., 2007). The temperature above and below the optimum temperature can alter the behavior of plant root exudation and microbial activity (Fageria and Stone, 2006). The change in soil water holding capacity might be cause for alteration of soil biology, plant root development, physiology of exudation, microbial mobilization and activity (Haichar et al., 2014). Aeration helps to regulate the better decomposition. Soil $\mathrm{pH}$ and heavy metal influence the plant and microbial physiology through soil acidification and redox reactions which can be altering the rhizospheric processes (Rajkumar et al., 2012). These changes in soil $\mathrm{pH}$ can increase the nutrients availability to plant especially $\mathrm{N}$, P, Ca, Mg, Fe and Zn (McNear et al., 2013). The healthy soil biology can be encouraged through supply of organic residues, crop residue management, apply compost/ manure, reduced tillage, minimum compaction, minimum use of pesticides along with growing cover crop or rotate the crop or intercrop for synergistic rhizosphere shaping (Li et al., 2007; Zimmerman et al., 2011; Pittelkow et al., 2014; Bender et al., 2016).

\section{Rhizosphere management to improve soil and plant productivity}

Rhizospheric management is the strategic management of plant, soil, and microbiota for improving the nutrient use efficiency, soil health, and plant productivity (Ryan et al., 
2009). Hence, the green revolution can't help for further increase in food production and the dependency on it causes a decline in soil health and crop productivity. So, we need to focus on the crop, soil and biological management strategies (Bender et al., 2016). These can categories under different management strategy and applied at various levels for gain maximum benefits. These management practices help us through manipulating specified biological communities and by improving the general biodiversity of rhizospheric soil (Dessaux et al., 2016). All the management categories are as follow:-

\section{Crop management}

Crop management considers both individual plant-based or complex diversified plant community management where both are modified or improved for efficient use of soil and plant resources. The individual plantbased root system can be improved for better rhizospheric activity (Bardgett et al., 2014). Lange et al., (2015) reported that the plant community can significantly enhance the microbial activity into the soil by improving soil organic matter status. Plants are the play an important role in rhizosphere designing through influencing soil biology. Bender et al., (2016) reviewed that the soil biology can be enhanced through the development of efficient, diverse and complementary approaches such as selection of the crop species and crop rotations. It can hasten the crop performance in particular soil environment due to improving the soil biology (Deguchi et al., 2007). The combined use of diversified selective crops and their cultivars provide an opportunity to exploit the soil biota, their traits and functions (Vandermeer et al., 1998). The soil biota and their processes are also accelerated in diverse cropping pattern by improved soil health. we can modify the soil biodiversity temporally (e.g., cover cropping and crop rotation) and spatially (e.g., intercropping and mixed cropping) through crops which gave the positive effect on agroecosystem ( $\mathrm{Li}$ et al., 2007). Which can help to manage the cropping system inherently and reduces the external input use (Bender et al., 2016)? Moreover, the crop management system can provide an opportunity to hastening the soil biotic potential, soil health, and crop performance.

\section{Soil management}

Soil management practices are done with the aim to improve tilth, weed-free condition, for preparation of stale seedbed and alteration of soil biotic potential as well as a reduction in economic assets. Soil biology can be hampered through tillage practices. However, it can provide an opportunity to improve nutrient use efficiency through promoting decomposition and mineralization activity of inorganic and organic sources (Zimmerman et al., 2011). The soil biotic potential can be hastened through improved soil management practices such as zero tillage, strip tillage, minimum tillage with the addition of cover crop and manures (Pittelkow et al., 2014). These soil management systems favor the soil biota development and decrease soil-borne pest infestation and weed population in a crop field (Mader et al., 2002). In the last half century, it found that soil amendments can be enhanced the soil health and plant output (Ryan et al., 2009). The N fixation and VAM activity can be accelerated by the biochar (Guerena et al., 2015). Biochar can increase the $\mathrm{pH}$ of acidic soils, water holding capacity of soil and hasten the rate of organic matter decomposition by enhancing the soil biological activity (Zimmerman et al., 2011). Dessaux et al., (2016) reviewed that the application of carbon-rich substrate such calcium silicate, organic residues, coal fly ash, and organic manure can improve soil 
biology, carbon status, mineralization and soil quality. Di Gregorio et al., (2006) reported that the inorganically accelerated Sinorhizobium sp. can significantly alter the soil biology and performance of Brassica spp. Lange et al., (2015) reported the addition of the organic matter can significantly accelerate the soil biological activity which helps to improvements in soil health, plant productivity through soil conservation and enhancing the soil boil diversity. So, all these added organic and inorganic soil amendments are helped to improving the soil health and plant performence.

\section{Microbiological management}

Soil biotic community help to improve the plant performance through solubilizing and mobilizing the organic and inorganic sources of nutrients and help to provide them to plant root such as PGPRs, VAM etc. (Ceballos et al., 2013).

Soil and seedling inoculation with the biotic community has positively influenced crop performance. Such as legumes inoculation with rhizobia spp. gave an opportunity to reduce plant external nitrogen demand due to nitrogen fixation (Vargas et al., 2000). However, these benefits mostly vary with soil type, plant type and environmental conditions (Kohl et al., 2016). In organic farming, agricultural pests control has also employed the biocontrol agents (Trichoderma, Pseudomonas, and Bacillus) which induce the plant systemic resistance against the pathogenic attack (Pieterse et al., 2014). Ryan et al., (2009) reviewed that the biotic community help to the production of certain types of the stress hormone, enzymes and another antibiotic which help to plant withstand under various stress conditions. So, the improvement in soil microbiota can help to improve plant productivity and provide environment safety.

\section{Rhizospheric biota management through Holobiont approach}

Researches evident that both plants and soil biota can shape the rhizosphere in collaborations (Bulgarelli et al., 2012). So, it has important for research purpose to breeding the plant community for improving the rhizospheric biodiversity with targeted functioning for crop plants (Muller and Sachs, 2015). The integration of plant and rhizospheric biota behavior with different breeding strategies can be fulfilling the requirements of agricultural sustainability (Chaparro et al., 2012). For example, root exudation and carbon allocation into rhizosphere have the source of energy for root symbionts (Walder and van der Heijden, 2015). The more carbon excreting crops can increase the rhizospheric biota and their activity. However, specified plant microbiome providing an opportunity for altering plant features, suppression of diseases (Mendes et al., 2011) and plant flowering time etc (Panke-Buisse et al., 2015). For example, a Bacillus spp. genetically altered for nitrogen fixation mechanism for production of higher concentrations and amount of plant hormones (Arkhipova et al., 2005; Kim and Timmusk, 2013).

A combined three-strain consortium such as Bacillus spp., Pseudomonas, Rhizobium or Bradyrhizobium which is improved nitrogen fixers could provide great opportunity of a diverse and complex natural rhizospheric biological functioning (Ahkami et al., 2017). The reduction in denitrification and Nitrogen losses from the soil through decreasing microbial activity by plants can improve the NUE (Skiba et al., 2011). The integrated development of plant and their rhizospheric microbiome can be an important step toward rhizospheric exploitation for better plant use efficiency (Bardgett et al., 2014). The research focused toward development and 
selection of the plant root and genotypes that have multitrait such as root developmental plasticity, WUE and root nutrient uptake will increase the crop yields in the changing climate (Ahkami et al., 2017) (Table 2).

The selection of the root characters are done on the basis of the spatial and temporal development of soil biology and there functioning. The diverse rooting habits can provide a more efficient way of soil biological interventions and nutrients dynamics. So, Bardgett et al., (2014) suggested that the root branching $[\mathrm{A}]$, root diameter $[\mathrm{B}]$, root specific length [C], exudation of rhizodeposits [D], VAM fungi association [E] and rhizobia symbiosis $[\mathrm{F}]$ are the most important root traits for better rhizospheric development. Desirable root traits are presented into the figure 1.

Table.1 Various plant root derivatives present into the rhizosphere

\begin{tabular}{|c|c|c|}
\hline $\begin{array}{l}\text { Plant derived } \\
\text { complexes }\end{array}$ & Description & References \\
\hline Exudates & $\begin{array}{l}\text { Diffused from root cortex zone to the intercellular } \\
\text { space later into the surrounding soil, broadest } \\
\text { spectrum effect on manipulation of rhizosphere high } \\
\text { concentration. }\end{array}$ & $\begin{array}{l}\text { Jones et al., 2009; } \\
\text { Haichar } \text { et al., 2014 }\end{array}$ \\
\hline Secretions & $\begin{array}{l}\text { Secondary products of root metabolic activities } \\
\text { released through cell via active transport and } \\
\text { improving mobilization of insoluble to soluble } \\
\text { compounds, as } \mathrm{P} \text { and Fe }\end{array}$ & Jones et al., 2009 \\
\hline $\begin{array}{l}\text { Senescence } \\
\text { derived } \\
\text { compounds/ } \\
\text { lysates }\end{array}$ & $\begin{array}{l}\text { All degenerated compound of the roots and its cell } \\
\text { that exerted into the rhizosphere, balance the C/N } \\
\text { ratio of soil organic matter. It includes nucleic acids, } \\
\text { lipids, various forms of carbohydrates and proteins. }\end{array}$ & Haichar et al., 2014 \\
\hline $\begin{array}{l}\text { Mucilage/ } \\
\text { Mucigel }\end{array}$ & $\begin{array}{l}\text { Slimy gel type coating or Gelatinous layer } \\
\text { surrounding the root tip. It consists of cellulose, } \\
\text { lignin, starch, pectin, and highly recalcitrant and } \\
\text { highly diversified C decomposers }\end{array}$ & Jones et al., 2009 \\
\hline Border cells & Sloughed off cells from the root. & $\begin{array}{l}\text { Jones et al., 2009; } \\
\text { Haichar et al., 2014 }\end{array}$ \\
\hline
\end{tabular}

Table.2 Effect of soil biota on soil, environmental and plant functions (modified from Bender et al., 2016)

\begin{tabular}{|l|l|l|}
\hline Functions & Through enhanced soil biota & Through improved soil biota \\
\hline Soil formation & Accelerate & \\
\hline Carbon sequestration & Improved & Improved \\
\hline Plant nutrient uptake & & Increased \\
\hline Nutrient losses & & Reduction \\
\hline Pathogenic attack & Reduced & Reduced \\
\hline
\end{tabular}


Table.3 The molecularly improved PGPRs for various plant functions (modified from Ahkami et al., 2017)

\begin{tabular}{|c|c|c|c|}
\hline Bacterial Species & $\begin{array}{l}\text { Plant } \\
\text { Species }\end{array}$ & Responses & Reference \\
\hline $\begin{array}{l}\text { Pseudomonas simiae } \\
\text { strain AU }\end{array}$ & Soybean & Systemic tolerance induction & $\begin{array}{l}\text { (Vaishnav et } \\
\text { al., 2015) }\end{array}$ \\
\hline Bacillus subtilis GB03 & Arabidopsis & Salt tolerance & $\begin{array}{l}\text { (Zhang et al., } \\
\text { 2010) }\end{array}$ \\
\hline $\begin{array}{l}\text { Gluconacetobacter } \\
\text { diazotrophicus PAL5 }\end{array}$ & Sugar cane & ABA signaling, drought tolerance & $\begin{array}{l}\text { (Vargas et al., } \\
\text { 2014) }\end{array}$ \\
\hline Streptomyces spp. & Chickpea & $\begin{array}{l}\text { Enhanced the activity of defense } \\
\text { mediated enzymes }\end{array}$ & $\begin{array}{l}\text { (Singh and } \\
\text { Gaur, 2017) }\end{array}$ \\
\hline $\begin{array}{l}\text { Azospirillum brasilense } \\
\text { Sp245 }\end{array}$ & Rice & $\begin{array}{l}\text { Nitrogen fixation and higher } \\
\text { activity the ethylene }\end{array}$ & $\begin{array}{l}\text { (Vargas et al., } \\
\text { 2012) }\end{array}$ \\
\hline $\begin{array}{l}\text { Dietzia natronolimnaea } \\
\text { STR1 }\end{array}$ & Wheat & salinity tolerance & $\begin{array}{l}\text { (Bharti et al., } \\
\text { 2016) }\end{array}$ \\
\hline
\end{tabular}

Figure.1 The representation of root characteristics that can be potential influences on the plantrhizospheric interactions (modified from Bardgett et al., 2014)

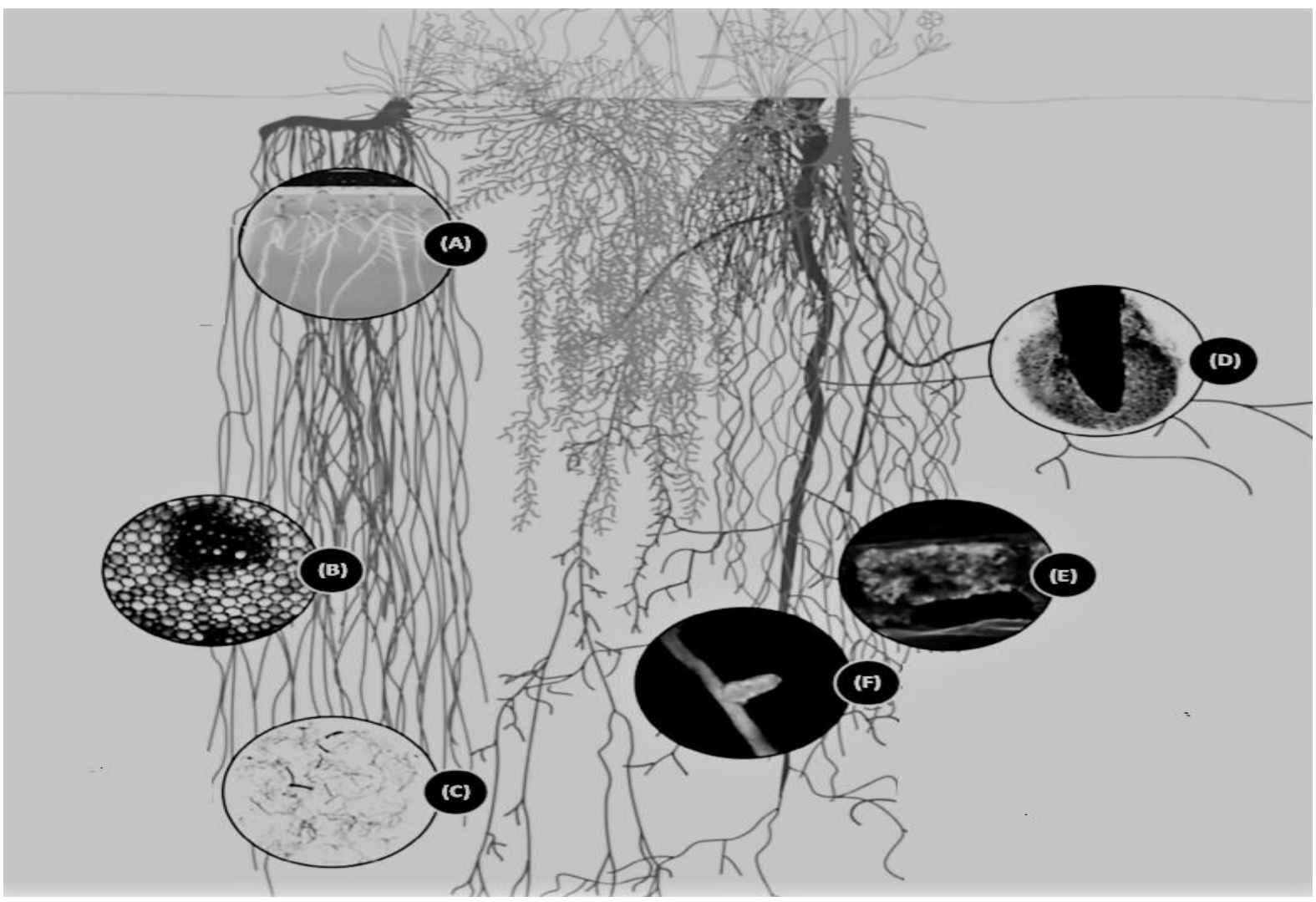


Plant and rhizospheric biotic community can also be improved through transgenic methods which can be helpful to develop the stress resistance cultivars or microbial stains that helpful for crop improvement (Bender et al., 2016). Some of such example molecularly engineered PGPRs for stress tolerance presented in table 3. So, the plant and rhizospheric community have great importance in enhancing plant performance and soil health in a sustainable manner.

In conclusion, the climate change, population pressure, and fate of green revaluation realize the importance of belowground development for increasing crop productivity. The soil portion where plant and soil biotic community are interact known as rhizosphere. It has greater impacts on soil physiochemical and biotic activities. In soil biological properties that most variables are soil biotic population, plant growth stimulatory activity and suppressor activity and plant-microbes signaling are the important processes that governed by the rhizospheric biota and plant interferences. In this mutualistic interrelation, the plant provides carbon as the food matter to soil biota and microbes increase the mineralization and availability of nutrient to plant by atmospheric nitrogen fixation, carbon, and nitrogen mineralization, phosphorus, potassium, and micronutrients through solubilization and mobilization process. So, the plant - microbes relationships can be potential use to enhance soil health and plant productivity.

Now, we need to focus on more toward rhizospheric biota and plant relationships and the plant breeding and microbiome engineering approaches to enhancing the plant- microbe's beneficial interference. It can help to enhance the various ecosystem services via carbon, nitrogen and water cycling, carbon utilization and storage, nutrient trapping, crop production. So, the overall improvement in rhizospheric plant microbe's interference can hasten the soil health, crop productivity and reduce the environmental pollutions.

\section{Future research orientations}

The rhizosphere is the core of all the physiochemical and biological activity that essential for plant growth and development. So, more understanding of the rhizospheric processes is essential for increasing plant productivity and soil quality.

It will be done through modulating the plant and microbial community, soil management and plant breeding and microbiome engineering for improvement in plant and microbial relationships.

Plant community will be the breed for characters such as plant root developmental plasticity, higher nutrient and water uptake, more biomass production and higher production of root exudates for better plantmicrobes interferences.

The biotic community will modulate for increase responses toward plant spp. by the use of biotechnology.

We shell need to development of such agrochemicals which can improved the plant microbe's interference.

The systemic approach where both plant and soil biota will be improved for better symbiosis and association through using plant breeding and biotechnological approaches.

All these aspects need to focus on future plant microbial strategies development to improvement in the rhizospheric responses toward plant community. 


\section{References}

Ahkami, A. H., White III, R. A., Handakumburaa, P. P., Jansson, C. (2017) Rhizosphere engineering: Enhancing sustainable plant ecosystem productivity. Rhizosphere. 3 (2017): 233-243.

Arkhipova, T.N., Veselov, S.U., Melentiev, A.I., Martynenko, E.V., Kudoyarova, G.R., (2005) Ability of bacterium Bacillus subtilis to produce cytokinins and to influence the growth and endogenous hormone content of lettuce plants. Plant Soil. 272: 201209.

Bardgett, R. D., Mommer, L., and De Vries, F. T. (2014). Going underground: root traits as drivers of ecosystem processes. Trends Eco Evol, 29(12): 692-699.

Bardgett, R.D. and van der Putten, W.H. (2014) Belowground biodiversity and ecosystem functioning. Nature. 515. 505-511.

Bender, S. F., Wagg, C., and van der Heijden, M. G. A. (2016) An Underground Revolution: Biodiversity and Soil Ecological Engineering for Agricultural Sustainability. Trends Ecol Evol. 31(6): 440-452.

Bharti, N., Pandey, S.S., Barnawal, D., Patel, V.K., Kalra, A., (2016) Plant growth promoting rhizobacteria Dietzia natronolimnaea modulates the expression of stress-responsive genes providing protection of wheat from salinity stress. Sci. Rep. 6: 34768.

Bommerco R, Kleijn D., Potts S.G. (2013) Ecological intensification: harnessing ecosystem services for food security. Trends Ecol Evol. 28(4):230-238.

Bulgarelli D, Rott M, Schlaeppi K, Ver Loren van Themaat $\mathrm{E}$, Ahmadinejad $\mathrm{N}$, Assenza F, Rauf P, Huettel B, Reinhardt R, Schmelzer E et al.
(2012) Revealing structure and assembly cues for Arabidopsis rootinhabiting bacterial microbiota. Nature. 488:91-95.

Ceballos, I., Ruiz, M., Fernández, C., Peña, R., Rodríguez, A., Sanders, I. R. (2013) The In Vitro Mass-Produced Model Mycorrhizal Fungus, Rhizophagus irregularis, Significantly Increases Yields of the Globally Important Food Security Crop Cassava. PLoS ONE, 8(8): e70633.

Chaparro, J. M., Sheflin, A. M., Manter, D. K., Vivanco, J. M. (2012) Manipulating the soil microbiome to increase soil health and plant fertility. Biol Fertil Soils. 48(5): 489-499.

Costa, R., Gotz, M., Mrotzek, N., Lottmann, J., Berg, G., and Smalla, K. (2006). Effects of site and plant species on rhizosphere community structure as revealed by molecular analysis of microbial guilds. FEMS Microbiol Eco. 56(2): 236-249.

Deguchi, S., Shimazaki, Y., Uozumi, S., Tawaraya, K., Kawamoto, H., and Tanaka, O. (2007) White clover living mulch increases the yield of silage corn via arbuscular mycorrhizal fungus colonization. Plant Soil. 291(12): 291-299.

Dessaux, Y., Grandclement, C., Faure, D., (2016) Engineering the rhizosphere. Trends Plant Sci. 21: 266-278.

Di Gregorio S, Barbafieri M, Lampis S, Sanangelantoni AM, Tassi E, Vallini G (2006) Combined application of Triton X-100 and Sinorhizobium spp. $\mathrm{Pb} 002$ inoculum for the improvement of lead phytoextraction by Brassica juncea in EDTA amended the soil. Chemosphere. 63:293-299.

Fageria, N. K., and Stone, L. F. (2006) Physical, Chemical, and Biological Changes in the Rhizosphere and Nutrient Availability. J. Plant Nutri., 
29(7): 1327-1356.

Guerena, D. T., Lehmann, J., Thies, J. E., Enders, A., Karanja, N., and Neufeldt, H. (2015) Partitioning the contributions of biochar properties to enhanced biological nitrogen fixation in common bean (Phaseolus vulgaris). Biol Fertil Soils. 51(4). 479-491.

Haichar F, Marol C, Berge O, Rangel-Castro J, Prosser J, et al. (2008) Plant host habitat and root exudates shape soil bacterial community structure. ISME J. 2:1221-1230.

Haichar FZ, Roncato M-A, Achouak W. (2012) Stable isotope probing of bacterial community structure and gene expression in the rhizosphere of Arabidopsis thaliana. FEMS Microbiol Ecol. 81:291-302.

Haichar, F. el Z., Santaella, C., Heulin, T., and Achouak, W. (2014) Root exudates mediated interactions below ground. Soil Biol and Biochem. 77: 69-80.

Harrier, L. A., and C. A. Watson. (2003) The role of arbuscular mycorrhizal fungi in sustainable cropping systems. Advan Agron. 20: 185-225.

Hartmann, A., Rothballer, M., Schmid, M., (2008) Lorenz Hiltner, a pioneer in rhizosphere microbial ecology and soil bacteriology research. Plant Soil 312, 7-14.

Hiltner L. (1904) Uber neuere erfahrungen und probleme auf " dem gebiete der bodenbakteriologie unter besonderer berucksichtigung der gr " und '. ungung und brache. ". Arb Dtsch Landwirtsch Ges;98:59-78.

Jiang, J.P., Xiong, Y.C., Jia, Y., Li, F.M., Xu, J.Z, Jiang, H.M. (2007) Soil Quality Dynamics Under Successional Alfalfa Field in the Semi-arid Loess Plateau of Northwestern China. Arid Land Res Mgt .21: 287-303.

Jones DL, Nguyen C, Finlay RD. (2009)
Carbon flow in the rhizosphere: carbon trading at the soil-root interface. Plant Soil. 321: 5-33.

Kim, S.B., Timmusk, S., (2013) A simplified method for gene knockout and direct screening of recombinant clones for application in Paenibacillus polymyxa. PLoS One 8.

Kohl, L., Lukasiewicz, C. E., and van der Heijden, M. G. A. (2015) Establishment and effectiveness of inoculated arbuscular mycorrhizal fungi in agricultural soils. Plant, Cell and Environ. 39(1): 136-146.

Lange, M., Eisenhauer, N., Sierra, C. A., Bessler, H., Engels, C., Griffiths, R. I., ... Gleixner, G. (2015). Plant diversity increases soil microbial activity and soil carbon storage. Nature Communications, 6(1).

Larsen, J., Jaramillo-López, P., NájeraRincon, M., and González-Esquivel, C. (2015) Biotic interactions in the rhizosphere in relation to plant and soil nutrient dynamics. J. Soil Sci. Plant Nutri. 15 (2): 449-463.

Larsen, J., Najera-Rincon, M., Esquivel Gonzalez, C., Gavito, M.E. (2015) Management of rhizosphere microorganisms in relation to plant nutrition and health. In: Agroecology, Ecosystems and Sustainability. CRC Press.

Li, L., Li, S.-M., Sun, J.-H., Zhou, L.-L., Bao, X.-G., Zhang, H.-G., and Zhang, F.-S. (2007) Diversity enhances agricultural productivity via rhizosphere phosphorus facilitation on phosphorus-deficient soils. Proceedings of the National Acad. of Sci., 104(27): 11192-11196.

Mader, P., Fliebbach A., Dubois D., Gunst L., Fried P., Niggli U. (2002) Soil fertility and biodiversity in organic farming. Science. 296: 1694-1697.

McNear Jr., D.H., (2013) The rhizosphere - 
roots, soil and everything in between. Nat. Educ. Knowl. 4, 1.

Mendes R, Kruijt M, de Bruijn I, Dekkers E, van der Voort $M$, Schneider JHM, Piceno YM, DeSantis TZ, Andersen GL, Bakker PA et al. (2011) Deciphering the rhizosphere microbiome for disease-suppressive bacteria. Science. 332:1097-1100.

Neumann, G., George, T. S., and Plassard, C. (2009) Strategies and methods for studying the rhizosphere - the plant science toolbox. Plant Soil. 321: 431456.

Panke-Buisse, K., Poole, A.C., Goodrich, J.K., Ley, R.E. and Kao-Kniffin, J. (2015) Selection on soil microbiomes reveals reproducible impacts on plant function. ISME J., 9: 980-989.

Philippot, L., Hallin, S., Börjesson, G., and Baggs, E. M. (2008). Biochemical cycling in the rhizosphere having an impact on global change. Plant and Soil, 321(1-2), 61-81.

Philippot, L., Raaijmakers, J.M., Lemanceau, P., van der Putten, W.H. (2013) Going back to the roots: the microbial ecology of the rhizosphere. Nat. Rev. Microbiol. 11: 789-799.

Pieterse CMJ, Zamioudis C, Berendsen RL, Weller DM, Van Wees SCM, Bakker (2014) PAHM: Induced systemic resistance by beneficial microbes. Annu. Rev. Phytophthora. 52:347-375.

Pittelkow, C. M., Liang, X., Linquist, B. A., van Groenigen, K. J., Lee, J., Lundy, M. E., van Kessel, C. (2014) Productivity limits and potentials of the principles of conservation agriculture. Nature, 517(7534): 365368.

Rajkumar, M., Sandhya, S., Prasad, M. N. V., and Freitas, H. (2012). Perspectives of plant-associated microbes in heavy metal phytoremediation. Biotechnology Advances, 30(6), 1562
1574.

Ryan PR, Dessaux Y, Thomashow LS, Weller DM (2009) Rhizosphere engineering and management for sustainable agriculture. Plant Soil. 321: 363-383.

Singh, S.P., Gaur, R., (2017) Endophytic Streptomyces spp. underscore induction of defense regulatory genes and confers resistance against Sclerotium rolfsii in chickpea. Biol. Control. 104: 44-56.

Skiba, M., George, T., Baggs, E., and Daniell, T. (2011) Plant influence on nitrification. Biochem. Soc. Trans. 39: 275-278.

Vaishnav, A., Kumari, S., Jain, S., Varma, A., Choudhary, D.K., (2015) Putative bacterial volatile-mediated growth in soybean (Glycine max L. Merrill) and expression of induced proteins under salt stress. J. Appl. Microbiol. 119: 539-551.

van Dam, N. M., and Bouwmeester, H. J. (2016) Metabolomics in the rhizosphere: tapping into belowground chemical communication. Trends Plant Sci. 21: 256-265.

Vandermeer, J., van Noordwijk, M., Anderson, J., Ong, C., and Perfecto, I. (1998) Global change and multispecies agroecosystems: Concepts and issues. Agri., Ecosys. Environ. 67(1): $1-22$.

Vargas, L., Santa Brigida, A.B., Mota Filho, J.P., de Carvalho, T.G., Rojas, C.A., Vaneechoutte, D., Van Bel, M., Farrinelli, L., Ferreira, P.C., Vandepoele, K., Hemerly, A.S., (2014) Drought tolerance conferred to sugarcane by association with Gluconacetobacter diazotrophicus: a transcriptomic view of hormone pathways. PLoS One 9, e114744.

Vargas, M. A. T., Mendes, I. C., and Hungria, M. (2000) Response of field-grown bean (Phaseolus vulgaris L.) to 
Rhizobium inoculation and nitrogen fertilization in two Cerrados soils. Bio. Ferti. Soils, 32(3): 228-233.

Walder, F. and van der Heijden, M.G.A. (2015) Regulation of resource exchange in the arbuscular mycorrhizal symbiosis. Nat. Plants. 1: 15159.

Whipps JM (2001) Microbial interactions and biocontrol in the rhizosphere. J. Exp. Bot. 52:487-511.

Wilson M, Lindow SE (1995) Enhanced epiphytic coexistence of near-isogenic salicylate-catabolizing and nonsalicylate-catabolizing Pseudomonas putida strains after exogenous salicylate application. Appl Environ Microbiol. 61:1073-1076.

Zhang, H.M., Murzello, C., Sun, Y., Kim, M.S., Xie, X.T., Jeter, R.M., Zak, J.C., Dowd, S.E., Pare, P.W., (2010) Choline and osmotic-stress tolerance induced in Arabidopsis by the soil microbe Bacillus subtilis (GB03). Mol. Plant-Microbe Interact. 23: 1097-1104.

Zimmerman, A. R., Gao, B., and Ahn, M.-Y. (2011) Positive and negative carbon mineralization priming effects among a variety of biochar-amended soils. Soil Bio. Biochem. 43(6): 1169-1179.

\section{How to cite this article:}

Arvind Kumar, V.P. Singh, D.S. Pandey and Rajeew Kumar. 2019. Rhizosphere Management: A Novel Approach for Improving the Crop Productivity. Int.J.Curr.Microbiol.App.Sci. 8(03): 2143-2155. doi: https://doi.org/10.20546/ijcmas.2019.803.257 